University at Albany, State University of New York

Scholars Archive

10-16-2017

\title{
Youth Developing Political Efficacy through Social Learning Experiences: Becoming Active Participants in a Supportive Model United Nations Club
}

\author{
Brett Levy \\ University at Albany, State University of New York, bllevy@albany.edu
}

The University at Albany community has made this article openly available.

Please share how this access benefits you.

Follow this and additional works at: https://scholarsarchive.library.albany.edu/etap_fac_scholar

Part of the Education Commons

\section{Recommended Citation}

Levy, Brett, "Youth Developing Political Efficacy through Social Learning Experiences: Becoming Active Participants in a Supportive Model United Nations Club" (2017). Educational Theory and Practice Faculty Scholarship. 34.

https://scholarsarchive.library.albany.edu/etap_fac_scholar/34

\section{(c) (i)}

This work is licensed under a Creative Commons Attribution 4.0 International License. This Article is brought to you for free and open access by the Educational Theory and Practice at Scholars Archive. It has been accepted for inclusion in Educational Theory and Practice Faculty Scholarship by an authorized administrator of Scholars Archive.

Please see Terms of Use. For more information, please contact scholarsarchive@albany.edu. 


\title{
Youth Developing Political Efficacy through Social Learning Experiences: Becoming Active Participants in a Supportive Model \\ United Nations Club
}

\author{
Brett L. M. Levy \\ University at Albany, State University of New York \\ bllevy@albany.edu
}

Citation information for published version:

Levy, B. L. M. (2018). Youth developing political efficacy through social learning experiences: Becoming active participants in a supportive Model United Nations club. Theory \& Research in Social Education, 46(3), 410-448, DOI: 10.1080/00933104.2017.1377654

\section{Acknowledgements:}

I would like to thank the scholars who provided feedback on earlier drafts: Jacquelynne Eccles, Annemarie Palincsar, Richard Niemi, Michaela Zint, Jianwei Zhang, Erica Halverson, Anita Wager, and Melissa Braaten. In addition, many thanks are due to this study's participants, who generously shared their thoughts, ideas, and experiences with me. 


\begin{abstract}
Prior research indicates that individuals are more likely to take political action (e.g., vote, contact representatives, protest) when they have higher levels of political efficacy, the belief that one's actions can influence political processes. In this mixed methods longitudinal study, I draw on Wenger's and Bandura's theories of social learning to examine how adolescents' political efficacy developed during their experiences in a Model United Nations club. Through analyses of data from questionnaires, interviews, and observations, I found that students' political efficacy increased as they became active club participants. Supportive relationships with club peers and advisors encouraged regular involvement, which in turn provided participants repeated opportunities to prepare for and practice authentic political tasks - experiences that supported their political efficacy. These findings enhance our understanding of successful democratic education and have useful implications for educators and researchers interested in political engagement.
\end{abstract}

\title{
KEY WORDS
}

civic education, civic engagement, extracurricular, out-of-school time, political efficacy, secondary education, social learning 
This article examines the development of political efficacy (sometimes called political self-efficacy), which is defined as the extent to which individuals believe they can influence the government (Campbell, Gurin, \& Miller, 1954). Political scientists have found political efficacy to be one of the most reliable predictors of various forms of political participation. Evidence indicates that political efficacy tends to increase when youth participate in certain interactive experiences, such as discussions of public issues (Hahn, 1998, 1999), but few published studies have examined how and why these experiences have this effect. To address this research gap, I employed mixed methods and a social learning framework to examine the experiences that support political efficacy development among students in an interactive political learning environment, a high school Model United Nations (UN) club.

Model UN is one of the world's largest political education programs, with over 400,000 participants each year worldwide (Williams, 2009). Increasingly common in under-resourced areas in numerous countries (United Nations Association of the USA, 2015), Model UN clubs and conferences provide students with opportunities to research, discuss, debate, and propose solutions to complex political problems, such as poverty, discrimination, and nuclear proliferation. Little research has examined how experiences in Model UN can support political efficacy or engagement. By analyzing high school students' experiences over the course of 7 months in the program, I identify opportunities and challenges involved in the development of political efficacy that will be useful for understanding not only Model UN but also a range of programs aiming to foster political engagement among youth.

\section{BACKGROUND}

To frame this study, I draw on research and theory from various fields, including political science, education, psychology, and the learning sciences. First, I explain the significance of 
political efficacy and self-efficacy, as well as prior research on how they develop. Then, I examine scholarship on adolescents' involvement in social experiences that could support the development of political efficacy, noting that little previous work has explicitly examined how social learning experiences can foster or strengthen political efficacy.

\section{Why Political Efficacy Matters}

One of the most consistent predictors of political participation is political efficacy (Abrams \& De Moura, 2002; Leighley \& Vedlitz, 1999). For decades, researchers have explored the effects, causes, and dimensions of this attitude (e.g., Button, 1972; Ehman, 1969, 1980), defining the concept as follows:

The feeling that individual political action does have, or can have, an impact upon the political process, i.e., that it is worthwhile to perform one's civic duties. It is the feeling that political and social change is possible, and that the individual citizen can play a part in bringing about this change. (Campbell et al., 1954, p. 187)

This belief in one's own ability to competently influence politics is an excellent predictor of various aspects of political participation, including voting (Becker, 2005), political activism (Abrams \& DeMoura, 2002), using informational news media (Newhagen, 1994), contacting public officials about issues of concern (Hirlinger, 1992), and psychological involvement in politics (Cohen, Vigoda, \& Samorly, 2001). Whereas external political efficacy (EPE) refers to the belief that the government will respond to citizens' demands, internal political efficacy (IPE) refers to a person's belief that he or she is able to understand politics and competently participate in political acts (Balch, 1974). Although these two dimensions are often closely correlated and 
studied as one coherent construct (Craig, 1979), some researchers consider them separately, as I do in this study.

Closely related to concepts of political efficacy is the concept of self-efficacy, defined as "a judgment of one's ability to organize and execute given types of performances" (Bandura, 1997, p. 21). Studies on the effects of various types of self-efficacy have similar findings to those of political efficacy. In short, when students believe that they are more competent at certain activities, they achieve greater success in those activities (Zimmerman, Bandura, \& MartinezPons, 1992), and increased levels of domain-specific self-efficacy have a positive influence on persistence for relevant tasks (Bandura, 2005). Because successful political action often requires numerous specific tasks, such as constructing arguments, supporting the development of political efficacy may require supporting the specific types of self-efficacy related to such tasks.

\section{Prior Research Related to Political Efficacy Development}

\section{Political Efficacy Development}

Prior research indicates that three types of experiences tend to support individuals' development of political efficacy: participating in authentic political processes, discussing political issues, and identifying with a political group. In exploring the effects of engaging in authentic political experiences, one study of adults in 22 countries (Ikeda, Kobayashi, \& Hoshimoto, 2008) found that participating in campaign activities can strengthen political efficacy, and analyses of large data sets in the United States (Clarke \& Acock, 1989), Australia (Stenner-Day \& Fischle, 1992), and Germany (Finkel, 1987) have found that voting and partisan action support increased political efficacy. Likewise, researchers have found that political efficacy among young people increases when they participate in small-scale democratic decision-making processes, such school-wide governance (Siegel, 1977), mock elections 
(Stroupe \& Sabato, 2004), and legislative role-playing games (Bernstein, 2008). Furthermore, recent research suggests that repeated experiences in democratic decision-making can support students' civic identity development (Lo, 2017; Lo \& Parker, 2016).

Such participatory activities may be managed in various ways (Wright-Maley, 2015a, 2015b) and thus produce different student outcomes. Some studies have found that political efficacy can decrease if participants feel excluded or unheard during political activities (Bowler \& Donovan, 2002; Freie, 1997). Disempowering simulation experiences (Livingston \& Kidder, 1972) and confusing political information (Lee, 2006; Miller, Goldenberg, \& Erbring, 1979) can reduce political efficacy. However, several studies indicate that overall, opportunities to discuss politics with peers (Morrell, 2005) or explore political information and perspectives (Wells \& Dudash, 2007), especially in an open classroom environment (Blankenship, 1990), tend to support individuals' beliefs that they can participate effectively in the political system.

Identifying strongly with a group, especially a politically oriented group, can also enhance individuals' political efficacy. Analyses of large-scale survey data from Canadian adults has indicated that identifying with a political party (Louis, Taylor, \& Neil, 2004), especially the party in power (Lambert, Curtis, Brown, \& Kay, 1986), tends to strengthen one's political efficacy. Studies of samples in the United States indicate that people have higher political efficacy if they identify strongly with a particular demographic group (Koch, 1993), participate in collaborative pluralist contexts (Beaumont, 2011), and feel more closely connected to their communities through personal relationships (Steinberger, 1981). Overall, these studies suggest that providing students with opportunities to work with others on political challenges may foster their political efficacy. 


\section{Self-Efficacy Development}

Like the research on political efficacy development, studies of self-efficacy indicate that certain formative experiences can positively influence self-efficacy judgments. For example, individuals can develop self-efficacy for various tasks by having "enactive mastery experiences" (Bandura, 1997, p. 80). By having opportunities to try and succeed at certain tasks, even in simulated environments, people can develop greater confidence in their abilities in those areas (Smith, 1989). In addition, individuals may gain self-efficacy through vicarious experiences by observing their peers succeeding at certain tasks, such as learning or developing skills (Bandura, 1997; Schunk, 1987).

Other factors can also influence self-efficacy. Verbal encouragement can heighten individuals' confidence in their abilities (Bandura, 1997). When students are told that they can succeed, they tend to succeed more often (Schunk \& Cox, 1986). Likewise, affective states can influence self-efficacy and intellectual resources (Fredrickson, 1998). Whereas low-anxiety individuals often find that stress and arousal facilitate performance, high-anxiety individuals may find such situations debilitating (Hollandsworth, Glazeski, Kirkland, Jones, \& Van Norman, 1979). Thus, the feedback and support that individuals receive during challenging situations may influence their development of political efficacy.

\section{Social Learning Processes}

Many of the aforementioned experiences that foster self-efficacy and political efficacy can occur when individuals learn to participate in communities of practice, that is, groups that engage in collective learning processes through shared experiences (Wenger, 1998). According to Lave and Wenger (1991), learning — whether involving the development of identity, knowledge, attitudes, or practices - occurs through active participation and co-participation, and 
individuals working with more experienced others may move from legitimate peripheral participation to more central participation. Whereas some individuals may be motivated to increase their involvement simply by observing and engaging with more experienced participants, others may require more explicit encouragement and guidance. Torney-Purta, Amadeo, and Andolina (2010) argued that such social processes are vital to explore in civic engagement research, and scholars have begun to do so.

Some researchers have found that guided youth activism groups can provide contexts for young people first to observe adults organizing events and then to collaboratively lead campaigns with more experienced activists where they can, for example, receive feedback from adults and peers about specific events and actions (Kirshner, 2008; Zeldin, Christens, \& Powers, 2013). Christens, Peterson, and Speer (2011) argued that involvement in such community organizations supports individuals' psychological empowerment, and Bixby's (2008) study of diverse urban youth involved in civic action suggested that socially rich political experiences can facilitate political efficacy and civic identity development. Likewise, Calabrese Barton and Tan (2010) found that social learning experiences can support shifts in attitudes toward political participation. In their study of low-income youth in an inter-active, exploratory summer science program, young people developed a greater sense of agency and began to identify as community science experts.

Engaging in civic issues with one's peers may be especially powerful. My earlier research $(2011,2016)$ and others' studies of activists (e.g., McAdam, 1988) suggested that individuals are more likely to have higher political efficacy if they perceive their peers to be involved in political issues. Furthermore, other studies indicate that interactively exploring international political issues with peers can enable adolescents to understand diverse view-points, 
consider the ethical dimensions of national citizenship (Myers, McBride, \& Anderson, 2015), and develop a more complex conception of the international system (Torney-Purta, 1989, 1996). Beaumont (2010) has theorized that such social learning experiences, such as involvement in a politically active community, can help adolescents view themselves as politically empowered. However, there has been little empirical research exploring specifically how social experiences can support pro-civic attitudes. This study examines the ways in which experiences in a politically oriented community of practice, a Model UN club, can help foster political efficacy.

\section{RESEARCH QUESTIONS}

Two research questions guided this study. First, to what extent and in what ways does students' political efficacy develop during their experiences in a politically oriented extracurricular club? Examining this question involved the collection and analysis of data from surveys and interviews that asked students over time about their political efficacy development. Second, what processes support (or detract from) students' development of political efficacy during their social experiences in Model UN? To explore this question, I focused on data from observations, interviews, and surveys to identify which aspects of students' experience most affected their participation in the club and their political efficacy.

\section{METHOD}

\section{Study Context}

This study involved the collection and analysis of quantitative and qualitative data in one high school Model UN club from mid-August 2009 through mid-March 2010. Model UN began in the 1940s, and ever since, the program's conferences have given secondary and university students opportunities to represent various countries in discussions and problem-solving 
exercises on a wide range of political issues (Turner, 1997). To prepare, students work within their school-based Model UN clubs or credit-bearing courses to conduct research on the topics that their conference committees will explore. Then at conferences, students work with others in caucuses to design and pass resolutions. In the process, students have the chance to observe, discuss, and collaborate with more experienced peers - expressing their countries' positions, hearing others' perspectives, and writing and voting on resolutions — and to learn by doing in communities of practice (Wenger, 1998). These patterns of activity make the program an ideal setting to explore the development of political efficacy through social learning.

The specific study site was the Model UN club at Elmwood High School (all names are pseudonyms), a secondary school in a middle-class semi-urban area bordering a major Midwestern city, during students' club-related experiences on and off school grounds. Elmwood High School enrolled about 1,650 students and had a 90\% graduation rate and an average ACT score of 21 . About $10 \%$ of its students were non-White. I selected this school's club because initial exploratory interviews indicated that it consistently included activities that researchers have found to be related to political efficacy development and social learning. Founded in the mid-1990s by a handful of students and one teacher, the club involved nearly 60 students per year and three faculty advisors-Mr. Kendall, Mr. Stein, and Ms. Paulson. During each year, the group brought between 20 and 35 students to four inter-scholastic conferences, and club members could also choose to participate in other club-based activities, including fundraisers, membership drives, elections, practice debates, and weekly club meetings.

During the study period, Elmwood's Model UN club (EMUN) attended three interscholastic conferences. Several weeks before each, students received their country and committee assignments based on their stated preferences and advisors' decisions. The club 
usually represented between four and seven different countries, depending on the number of EMUN students attending a conference. After country assignments, students began conference preparation, which included independent research, meeting with an advisor, country delegation meetings, and preparing "position papers" that clarified their stances on issues assigned to their committees. Once at a conference, students attended their committees' sessions, which involved debates and discussions about these topics.

Members also had opportunities to serve in various leadership positions. The club's nine officers attended and organized meetings each Friday after school, and any member also could serve as event coordinators or country delegation leaders for a conference. Club advisors expected students to lead most club activities, and although they were often present and responsive, advisors encouraged students to make most decisions (see Levy, 2011, 2013). Although this group's size and activity is not representative of other such clubs, it was a useful context in which to examine the social experiences that contribute to students' political efficacy.

\section{Participants}

This study included 36 members of EMUN and, for the purposes of comparison, 27 members of the school's National Honor Society (NHS). I selected NHS as the comparison group because the backgrounds of its participants were similar to those of EMUN students (see Appendix A). Students in both groups, on average, had GPAs over 3.5, at least one parent with a four-year college degree, and similar levels of political efficacy. Whereas participation in EMUN involved exploring political issues, NHS required 20 hours of independent community service per academic year and no interactive political learning. The similarity of these groups allows for useful comparisons about how EMUN experiences relate to political efficacy development. 
Among the quantitative EMUN sample, there was a variety of participation levels. Whereas half attended two or three conferences during the study period, seven attended one, and eleven attended none. Twenty-six members reported attending meetings every two weeks or more often, but fewer students participated in fundraisers. About half of the EMUN sample indicated that they had at least eight friends in the group, but ten indicated that they had two friends or fewer. Thus, whereas the club involved numerous supportive relationships, some members were less socially integrated.

\section{Data Collection}

I gathered three major types of data during students' Model UN experiences: interview data, questionnaire responses, and records of observations. All interviews and most observations were audio-recorded. Throughout the study, I observed students' weekly full club meetings each Monday and officer meetings each Friday. In addition, I observed conference preparation activities and attended three interscholastic conferences, observing EMUN students in committee meetings, informal discussions, and exchanges with advisors. Throughout these observations, I recorded field notes about the experiences of EMUN students, especially those of nine focal participants.

As I recorded field notes on a laptop computer, I attended closely to EMUN members' opportunities to become involved in discussions, decision-making, and leadership roles. I created separate files for each meeting and conference committee. These files included three columns, the left column noting start and end times for particular events, the center column containing details about verbal exchanges and physical movements, and the final right-most column allowing space for commentary and initial codes. The total duration of my observations was approximately 150 hours. 
The questionnaires, which I administered in September (Time 1) and February (Time 2), measured students' political efficacy and asked about their backgrounds, including age, race, GPA, and parents' levels of education. I also measured their political interest as a control variable, given that this attitude often influences students' choice to participate in political activities (Leighley \& Vedlitz, 1999). The two groups' questionnaires were nearly identical at both time points, but the EMUN students' second questionnaire included some additional questions about the EMUN events they attended (conferences, fundraisers, meetings) and the number of friends they had in the club.

To prepare for the present study, I conducted two pilot studies on political efficacy. My findings indicated that IPE has two sub-dimensions, one related to political skills and another related to political knowledge, and that EPE differs across levels of government. I used, adapted, and designed survey items to reflect these findings (see Appendix B). To measure knowledgebased IPE (IPE/knowledge), an individual's self-efficacy for understanding political facts and concepts, I included items from the American National Election Study (Craig, Niemi, \& Silver, 1990). And to measure skills-based IPE (IPE/skills), a person's self-efficacy for performing politically relevant tasks such as constructing reasoned arguments, I adapted items from a study of managers (Paglis \& Green, 2002). To measure EPE, I included items emerging from my study of adolescents' conceptions of political efficacy, which indicated that young people have different perceptions of their political influence at different levels of government. Finally, to measure political interest, a control variable, I adapted a question from research on the expectancy-value model (Eccles, 2005; Wigfield \& Eccles, 2000), a prominent social science theory positing that individuals' choices are based on both their expectations of successful outcomes and how valuable they consider the relevant task(s). 
In addition to surveys and observations, I conducted focused semi-structured interviews (Merton, Fiske, \& Kendall, 1990) with nine focal students. These students were selected to include variation by sex, prior experience in EMUN, and involvement in club activities. However, on average they attended more conferences than other club members. Among them were three freshmen, three upperclassmen new to EMUN, and three veteran members who also served as club officers (see Table 1). I spoke with each student individually at least four times, once at the beginning and end of the study period and twice or more during their conference and club experiences. A few additional interviews occurred in pairs or small groups. During initial and final interviews, usually between 15 and 30 minutes, I asked students about their political efficacy and interest, reasons for participating in EMUN, and experiences in the club. Additional interviews, usually about five minutes, occurred during conferences and after club meetings and asked students about their ongoing experiences and learning. Besides these focal students, I conducted one or more interviews with 14 other EMUN members to examine the themes, commonalities, and differences among a broader sample.

\section{Data Analysis}

Exploring answers to my research questions required several types of data analysis. First, I examined my qualitative data. Using the constant comparative method (Glaser \& Strauss, 1967; Strauss \& Corbin, 1999) and NVivo soft- ware, I conducted open coding of interview transcripts and field notes throughout the data collection process, and I repeatedly revised, combined, and reorganized these codes. Among my major coding categories were the three dimensions of students' political efficacy: EPE, IPE/skills, and IPE/ knowledge. Within each of these coding categories, I examined each focal student's (and other participants') comments over time, looking for longitudinal trends and discrepant data. 
Table 1. Student Interviewees

\begin{tabular}{llcclccc}
\hline Name & Sex & Age & Grade & Status in Club & $\begin{array}{c}\text { \# Conferences } \\
\text { During Study }\end{array}$ & \# Interviews & \# Interview \\
Minutes
\end{tabular}

I also created codes to characterize the general experiences of club members. These broad codes included data from interviews and observations related to students developing relationships, using political knowledge, practicing political skills, setting/pursuing collective goals, and achieving collective goals. Within each of these codes, I developed subcategories. For example, in the category on developing relationships, I used observation data to identify specific experiences that provided relationship-building opportunities (see Appendix C). This coding process resulted in several dozen codes and sub-codes. While specifying and revising codes, I wrote analytic memos to explore my coding dimensions and relationships among them. The summary of findings below includes examples that illustrate the general trends in my data.

In addition to coding qualitative data, I analyzed students' questionnaire responses in order to understand group characteristics and identify differences in participants' political efficacy and EMUN participation. First, I conducted cross-tabulations, $t$-tests, and analyses of variance to compare characteristics of NHS and Model UN students. Then, I examined EMUN members' questionnaire data by conducting frequency analysis on several variables, such as those related to participation in certain club activities and perceived friendships in the club. 
To construct political efficacy scales, I conducted principal component analysis (with varimax rotation) with conceptually relevant items at Times 1 and 2 , which enabled me to identify how participants' responses were similar or different across items — and to deduce which combinations of items captured key underlying constructs. Results indicated that political efficacy comprised three coherent constructs: EPE, IPE/knowledge, and IPE/skills. At both time points, item cross-loadings above .3 were minimal (two items at Time 1 and one item at Time 2), and in such cases, I constructed scales based on the conceptual underpinnings of the scale. Scales for each construct at Times 1 and 2 included the same items at both time points.

In addition, I created a scale to capture students' involvement in EMUN activities, which included the sum of the variables for students' participation in conferences, fundraisers, and club meetings (see Appendix A). Students' mothers' and fathers' education levels were closely related, so I combined these variables into a single seven-level scale. All scales had acceptable alpha values, with all but one over .7. To convert these scales to variables, I calculated means of the relevant items. (For items and levels, see Appendix B, Table B1.)

To examine the characteristics and experiences related to political efficacy development and EMUN participation over time, I first calculated correlations and $t$-tests with data from Times 1 and 2 to compare EMUN and NHS students. Next, I conducted several ordinary least squares regression analyses. Controlling for students' background characteristics and initial levels of political interest and efficacy, I examined the extent to which Model UN participation was associated with higher political efficacy at Time 2. Also, I conducted regression analyses examining the relationship between students' number of friendships with club members and their participation in EMUN activities. 
For all of these models, when variables had limited or no effects, I removed them from the regression calculations, which helped to increase the equations' degrees of freedom. Due to missing data on certain variables, the sample size in the regression models is smaller than the overall sample. Regression models can involve independent (predictor) variables that are highly correlated, which can lead to distorted effect sizes for such variables, so it is important to assess their multi-collinearity (i.e., the relationships among independent variables). Thus, for each regression model, I assessed multi-collinearity by examining the variance inflation factors. These assessments enabled me to more accurately measure the extent to which the predictors in each model independently influenced the outcome variable.

\section{FINDINGS}

The findings of this study indicate that participating in Model UN supported students' political efficacy and that this attitude became stronger as students became increasingly active, central participants in the club. Below is a detailed summary of findings divided into two major sections. First, I share my analyses of the ways and extent to which EMUN students developed greater political efficacy. Then, I describe the social learning experiences that enabled EMUN members to become more active participants in the club.

\section{Political Efficacy Development Through Model UN}

\section{T-Test Results}

Results of $t$-tests indicate that Model UN participation was related to higher levels of political efficacy (see Table 2). At the beginning of the study, EMUN and NHS students had equivalent levels of IPE/skills and EPE, but just five months later, EMUN students measured significantly higher than NHS students on these scales. Whereas EMUN students maintained 
Table 2. Results of T-tests Examining Differences between Student Groups' Political Efficacy at Time 1 and Time $2(N=63 ; E M U N N=36, N H S N=27)$

\begin{tabular}{lcccc}
\hline & \multicolumn{2}{c}{$\begin{array}{c}\text { Time 1 } \\
\text { September, 2009 }\end{array}$} & \multicolumn{2}{c}{$\begin{array}{c}\text { Time 2 } \\
\text { February, 2010 }\end{array}$} \\
\cline { 2 - 5 } Scale & NHS Students & EMUN Students & NHS Students & EMUN Students \\
\hline IPE/Skills & $5.1(0.8)$ & $5.4(0.7)$ & $5.0(0.9)$ & $5.7^{* * *}(0.6)$ \\
IPE/Knowledge & $4.6(0.7)$ & $5.0^{*}(1.1)$ & $4.3(0.9)$ & $5.2^{* * *}(0.9)$ \\
External Political Efficacy & $4.3(1.3)$ & $4.6(1.0)$ & $3.7(1.0)$ & $4.6^{* * *}(0.9)$ \\
\hline
\end{tabular}

Note: $* * * \mathrm{p}<.001, * * \mathrm{p}<.01, * \mathrm{p}<.05, \sim \mathrm{p}<.1$

their initial EPE levels, those of NHS students declined $(\mathrm{p}<.05) .{ }^{1}$ On IPE/knowledge, there were similar shifts. Whereas EMUN students had higher IPE/ knowledge than NHS students at the beginning of the study, this difference increased substantially between Times 1 and 2 .

\section{Changes in EMUN Members' IPE/Skills}

My analyses indicate that students' EMUN participation had a positive influence on students' IPE/skills. First, results of regression analysis showed that participants in Model UN had Time 2 IPE/skills that were about .26 standard deviations higher than that of NHS members $(\mathrm{p}<.05)$, controlling for age, parental education levels, and Time 1 political efficacy and interest. Initial IPE/skills levels also had a substantial effect on IPE/skills at Time $2(\mathrm{p}<.001)$. The variables in the model (see Table 3, Model 1) explained 62 percent of the variance in students' IPE/skills at Time 2.

My qualitative data echo these findings. In interviews, several participants expressed their belief that their Model UN experiences had strengthened their skills at communicating, negotiating compromises, and working cooperatively with others. Like nearly every interviewee, Julia commented on her stronger public speaking skills, explaining that "through Model UN I've really learned how to go up in front of people and talk" (interview, February 8, 2010). 
Meanwhile, Brad noted that his experiences in debates had made him better at the "art of persuasion" (interview, March 8, 2010). Several others told me that working in committees with delegates representing various countries had strengthened their ability to find common ground. As Sarah recalled, "You have to come up with something that will satisfy as many countries as possible.... You need to be able to communicate, accept what others say, and talk to people in a way that doesn't offend people" (interview, February 5, 2010). Thus, there is strong evidence that participating in EMUN supported various aspects of students' IPE/skills.

\section{Changes in EMUN Members' IPE/Knowledge}

There were also increases in students' knowledge-based political efficacy. EMUN members had Time 2 IPE/knowledge that was .22 standard deviations higher than that of NHS members, controlling for age, parental education, and Time 1 political interest and efficacy $(\mathrm{p}<$ .05; see Table 3, Model 2). My analyses also indicate that students who participated in more EMUN activities had greater gains in IPE/knowledge than those who were less involved $(\mathrm{p}<.05$; see Table 3, Model 3). In both models, initial IPE/knowledge and IPE/skills levels also had a substantial effect on IPE/knowledge at Time $2(\mathrm{p}<.001)$.

Likewise, my qualitative analyses also suggested that EMUN students developed substantial IPE/knowledge during their experiences in the club. Most interviewees could point to many international political issues they had learned about during EMUN, and experienced members believed that their knowledge had grown with each conference. As senior Evelyn explained, “I think I've been introduced to a lot more areas of international politics that I hadn't been familiar with before I joined the club, such as the World Health Organization.... There are also conflicts around the globe that I probably wouldn't be aware of if they weren't topics for Model UN conferences" (interview, September 16, 2009). Overall, both my quantitative and 
Table 3. Standardized Betas (and Standard Errors) of OLS Regression Models Examining Students' IPE/Skills and IPE/Knowledge at Time $2(N=58 ; E M U N N=35$; NHS N=23)

\begin{tabular}{lccc}
\hline & \multicolumn{2}{c}{ Internal Political Efficacy (IPE) Outcome Scales } \\
\cline { 2 - 4 } & $\begin{array}{c}\text { (Model 1) } \\
\text { IPE/Skills, } \\
\text { Independent Variables }\end{array}$ & $\begin{array}{c}\text { (Model 2) } \\
\text { TPE/Knowledge, } \\
\text { Time 2 }\end{array}$ & $\begin{array}{c}\text { (Model 3) } \\
\text { IPE/Knowledge, } \\
\text { Time 2 }\end{array}$ \\
\hline Parental Education & $-.04(.06)$ & $-.11(.06)$ & $-.11(.06)$ \\
Age & $.08(.19)$ & $-.01(.20)$ & $-.03(.20)$ \\
Political Interest, Time 1 & $.13(.06)$ & $.04(.06)$ & $.08(.06)$ \\
EPE, Time 1 & $-.03(.07)$ & $.15(.07) \sim$ & $.16(.07) \sim$ \\
IPE/skills, Time 1 & $.61(.11)^{* * *}$ & $.19(.12)^{*}$ & $.23(.12)^{*}$ \\
IPE/knowledge, Time 1 & $.06(.11)$ & $.59(.11)^{* * *}$ & $.57(.11)^{* * *}$ \\
Participation in Model UN & $.26(.17)^{*}$ & $.22(.18)^{*}$ & -- \\
Number of EMUN Activities & -- & -- & $.57(.11)^{*}$ \\
Constant & 1.77 & .31 & $-.25(.69)$ \\
$\mathrm{R}^{2}$ & $.62^{* *}$ & $.73^{* * *}$ & $.72 * * *$ \\
\hline Note: ***p<.001, **p<.01, *p<.05, $\sim \mathrm{p}<.1$ & & &
\end{tabular}

qualitative findings indicate that students developed greater IPE/knowledge during their experiences in the club.

\section{Changes in EMUN Members' EPE}

Participating in EMUN also supported students' EPE. Students who participated in EMUN had Time 2 EPE that was over .3 standard deviations higher than that of NHS members, controlling for age, parental education levels, and Time 1 political interest and efficacy $(\mathrm{p}<.05$; see Table 4). In addition, students' Time 1 political interest was marginally related to their Time $2 \mathrm{EPE}$, which suggests that political interest may be important for fostering political efficacy over time. $^{2}$

Qualitative analyses also indicated that students' participation in Model UN supported their EPE. At the beginning of the study, most new Model UN students expressed a general belief that their actions could influence the government but could offer few concrete details. 
Table 4. Standardized Betas (and Standard Errors) of OLS Regression Models Examining Students' External Political Efficacy at Time 2 (Total N=57; EMUN N=35, NHS N=22)

\begin{tabular}{lc}
\hline Independent Variables & External Political Efficacy. Time 2 \\
\hline Parental Education & $-.18(.10)$ \\
Age & $-.08(.31)$ \\
Political Interest, Time 1 & $.09(.10) \sim$ \\
External Political Efficacy, Time 1 & $.41(.11)^{* *}$ \\
IPE/skills, Time 1 & $-.01(.18)$ \\
IPE/knowledge, Time 1 & $-.02(.18)$ \\
Participation in Model UN & $.34(.29)^{*}$ \\
Constant & $3.41^{* *}$ \\
$\mathrm{R}^{2}$ & $.40^{* * *}$ \\
\hline$* * * \mathrm{p}<.001, * * \mathrm{p}<.01,{ }^{*} \mathrm{p}<.05, \sim \mathrm{p}<.1$ &
\end{tabular}

Their comments at the end indicated a broader understanding of the means they could use to accomplish their civic goals. Erin, for example, at the beginning of the study, told me, "At this moment, all I can do to make a difference would be to write a few letters" (interview, November 9, 2009). Just a few months later, however, she demonstrated greater understanding of civic action by starting a Facebook group for people interested in supporting Elmwood High's arts program, recently threatened with budget cuts. The group had attracted over 600 members by March. Other club members, including Brad, Julia, Sarah, and Evelyn, also explained that their EPE had become more robust during their Model UN experiences, and many of them had clearer ideas of steps that they could take to try to influence the outcomes of political processes. Whereas some EMUN members developed some political cynicism as they became increasingly aware of political challenges, most interviewees indicated that, overall, the EMUN experience had made them feel politically competent and empowered at the local level, if not more broadly. 


\section{Processes Facilitating Participation and Political Efficacy Development}

In this section, I explain how students became increasingly active participants in Model UN and how these experiences ultimately facilitated their political efficacy development. Central to maintaining and increasing members' EMUN participation were their supportive relationships with EMUN peers and advisors. As these relationships encouraged continual engagement in the club's activities, such as meetings and conferences, participants had repeated opportunities to actively engage in authentic political tasks. The latter opportunities enabled many participants to have successful political learning experiences, which appeared to support their political efficacy. Below, I elaborate on each aspect of this process.

\section{Supportive Relationships}

EMUN activities were optional, and one major reason that members chose to participate in them was the relationships with others in the program. Results of OLS regression indicate that students were more likely to participate in conferences, fundraisers, and club meetings if they reported having more friends in the club, controlling for age, parental education, and initial levels of political efficacy and interest $(\mathrm{p}<.001$; see Table 5$){ }^{3}$

Indeed, many students joined the club due to an initial social connection, either with a peer or club advisor. Julia joined the group as a junior after one of her friends in the club suggested that she join, and Carol became a member with several of her friends from middle school, all of whom sat together in club meetings. Evelyn joined during her sophomore year after a club officer personally invited her to do so, and she then convinced one of her friends to join. From there, she began to befriend older students who shared common interests, including a desire to learn about the community and world (interview, September 16, 2009). 
Table 5. Unstandardized Betas (and Standard Errors) of OLS Regression Models Examining Relationships between More Student Friendships and EMUN Activities (EMUN N=32)

EMUN Activities Outcome Variables

\begin{tabular}{lcccc}
\cline { 2 - 5 } $\begin{array}{l}\text { Independent } \\
\text { Variables }\end{array}$ & $\begin{array}{c}\text { HS Conferences } \\
\text { Attended }\end{array}$ & $\begin{array}{c}\text { Fundraiser } \\
\text { Participation }\end{array}$ & $\begin{array}{c}\text { Meeting } \\
\text { Frequency }\end{array}$ & $\begin{array}{c}\text { Overall } \\
\text { Participation }\end{array}$ \\
\hline Parental Education & $-.07(.28)$ & $-.13(.10)$ & $-.23(.14) \sim$ & $-.14(.45)$ \\
Age & $.27(.88) \sim$ & $.03(.34)$ & $.02(.45)$ & $.15(1.4)$ \\
Pol. Interest, Time 1 & $-.05(.39)$ & $-.14(.15)$ & $-.17(.20)$ & $-.12(.63)$ \\
EPE, Time 1 & $.01(.39)$ & $-.03(.15)$ & $.06(.20)$ & $.02(.64)$ \\
IPE/skills, Time 1 & $-.20(.75)$ & $-.16(.28)$ & $-.18(.38)$ & $-.20(1.2)$ \\
IPE/knowledge, Time 1 & $.39(.57) \sim$ & $.34(.22) \sim$ & $.32(.29) \sim$ & $.39(.92)^{*}$ \\
More EMUN Friends & $.77(.11)^{* * *}$ & $.89(.04)^{* * *}$ & $.91(.06)^{* * *}$ & $.90(.18)^{* * *}$ \\
Constant & $-.07(4.0)$ & $1.2(1.5)$ & $2.3(2.1)$ & $3.5(6.5)$ \\
$\mathrm{R}^{2}$ & $.56^{* *}$ & $.74^{* * *}$ & $.75^{* * *}$ & $.72^{* * *}$ \\
\hline
\end{tabular}

Through participating in activities with politically interested peers, many EMUN members strengthened these personal relationships. Evelyn explained that these relationships made their work together more enjoyable and productive:

In Model UN, a lot of us are good friends. We spend a lot of time together outside of school or [the club]. And I think doing a fundraiser or an advocacy project are [sic] a lot easier to work on when you get to work on them with people that you enjoy spending time with. (interview, September 16, 2009)

For Evelyn and other EMUN members, positive relationships with EMUN peers made club activities valuable and worth continuing. Club members and advisors were aware of the importance of these relationships and undertook efforts to foster them among new members, planning structured bonding experiences and informal time during Model UN gatherings (see Appendix C). Meanwhile, the ongoing support, availability, and encouragement of club advisors also helped sustain EMUN members' participation. 


\section{Attentive Preparation for Action}

Becoming active participants in EMUN activities included various forms of preparation — both implicit and explicit. Whereas some members appeared to learn participation strategies through observing peers, others required clearer direction from advisors and peers to help them prepare for their own increasing involvement (see Levy, 2016 for details on advisors' roles). In both cases, such guidance gave members the chance to consider ideas and practice skills relevant to upcoming tasks.

Thoughtful observation. At meetings and conferences, a large proportion of most participants' time was spent observing others. Advisors and senior club members regularly communicated to newer members that non-participation was fine and even expected and that noticing and studying other students' actions was valuable. Although some participants appeared intellectually disengaged during some lengthy meetings, most who attended regularly appeared to attend closely to ongoing events, even noting subtle strategies and movements.

For example, at Julia's first full-day conference, she felt she “didn’t know what was going on" (interview, October 24, 2009) and spent the morning observing others in her committee, but by the early afternoon, she was asking questions of the speakers who presented their resolution, gradually becoming more involved. By the end of the day, she made a speech and worked with others to write a resolution. Then during her second conference, which lasted three full days, she moved beyond developing familiarity with the conference procedures and became more attuned to subtle strategies that delegates used to have their voices heard:

I like to, like, watch how other people do things and learn how they interact.... I noticed that [the student delegate from] Japan will put his hand on the table and physically lean in and put himself literally in the center of the circle.... So now I 
make sure that I stay physically close to what's going on, not pushed out to the side where no one can hear or see you. (interview, January 16, 2010)

During this conference, Julia appeared to develop more confidence in her political skills as she become heavily involved in debates, caucuses, and writing resolutions.

Carol had a similar process of attentively observing and then becoming more involved, but the process was more gradual. At her first conference in October, she made no speeches and did not become involved in writing resolutions. Reflecting on the conference, she told me that she had felt unprepared compared to other students but that, after observing others, she hoped to prepare more for the next conference. Then, at November's interscholastic gathering, she gave two speeches and worked with others on a resolution. After seeking and receiving public speaking guidance from an advisor, she gave four short speeches at January's conference and wrote a resolution with another delegate. Looking back, she noted that observing others had strengthened her understanding of how to address the issues under discussion and had made her feel more comfortable offering her perspectives (interview, January 15, 2010).

Experienced members, such as Randall, told me their early experiences in the club had been similar to Julia's and Carol's in that attentive observations were a vital aspect of their learning about various practices in the club. When I asked Randall how he learned his strategy for securing votes for his resolution, he told me the following:

It's just something I noticed from the last couple years. The more experienced delegates will just come up to you with an amendment and say, "I know you supported the original resolution. This barely changes anything, so will you support it?" Assuming you agree with it. It sort of tricks you into agreeing with it, but you still feel like it's your own choice. (interview, December 12, 2009) 
Because students and advisors recognized this process, the officers planned demonstration debates during club meetings shortly before conferences (field notes, October 12, 2009) and invited newly elected officers to observe current officers' meetings before assuming their new positions (field notes, March 5, 2010 \& March 19, 2010). Observing other delegates helped new members become aware of the content, skills, and strategies required to become more involved in the program.

Guided preparation. EMUN participants also sought and received explicit guidance from advisors and peers to help them prepare for their active involvement. Such guidance was common during conference preparation. Several weeks before each conference, members met after school with or without an advisor to conduct research on their countries' positions, get feedback on position papers, and outline their initial speeches. During these experiences, new members often asked questions or received direct instruction from advisors or more experienced peers, but they also were expected to expend effort preparing themselves.

At one such meeting, Carol and three other freshmen prepared to represent Turkey by meeting in the school library one afternoon three weeks before their first multi-day conference. They first spent a half-hour sharing what they each had learned about the country's positions on various issues, and then Mr. Kendall joined them to answer questions and provide some background on Turkey. Over the following weeks, Mr. Kendall held follow-up meetings to discuss their position papers, and during the conference he met individually with one of them for over 30 minutes to help her understand the perspectives of other delegates on her committee.

During this study, there were numerous instances when advisors or experienced EMUN members met with new members to prepare them to participate in certain activities. To create a welcoming conference preparation environment, Mr. Kendall reserved a room at a public library 
for two full days during Elmwood's holiday break. Over a dozen students came each day to conduct research and listen to Mr. Kendall's mini-lectures on international issues.

Whereas many of the aforementioned activities were aimed at fostering participants' political knowledge, advisors and experienced EMUN members also helped new members develop political skills and strategies before and even during conferences. For example, in one after-school meeting, Mr. Kendall provided Carol with suggestions for getting more involved at conferences. At the January conference, Julia regularly sought "real time" guidance from a seasoned peer. Julia expressed gratitude for the support she had received from an experienced EMUN member in her committee:

My first conference, you don't know what's going on completely and it's important to know someone that you can ask questions to, or even discuss your ideas with.... I went to Jerry like a million times 'cause he was on my committee.... I got good advice from him.... I think it's important to have friends or someone you know [on your committee]. I never knew him before this. (interview, February 8, 2010)

In their conference committees, new EMUN members often sat with experienced members and regularly spoke to them, and during committee breaks, EMUN members often met in spontaneous groups in hallways for a mixture of debriefing and sharing advice. Through informal exchanges, new members received guidance on how to meet their goals in their committees, and this advice helped prepare them to practice authentic political tasks.

\section{Practicing Authentic Political Tasks}

EMUN members had repeated opportunities to engage in tasks related to authentic political action, including practicing political skills and pursuing collective goals. These 
experiences appeared to support their political efficacy development, particularly when resulting in successful outcomes.

Pursuing collective goals. EMUN members' experiences at conferences and within the club provided opportunities to pursue collective goals, which is often a central feature of political action. At conferences, students joined with delegates from their own club and other schools to design potential solutions to international challenges-forming alliances, working in teams, lobbying potential allies, and voting on measures. For example, during the January conference, several members of Julia's committee designed a resolution to support stronger women's rights in Africa. She gave speeches in favor of the bill and proposed an amendment emphasizing the importance of national sovereignty. The committee eventually voted to pass Julia's proposed amendment and thereafter passed the resolution. Reflecting on this experience, Julia said,

I was able to take the initiative and I felt really good about that.... It invokes the thought, "If I can be here and we can all come to these agreements together, what can we do beyond this place?" (interview, January 17, 2010)

The experience of pursuing and achieving collective goals had helped Julia envision herself taking effective political action beyond Model UN, and other participants made similar comments.

In post-conference interviews, every participant offered stories about how they had contributed in some way to the development or passage of a resolution, either by authoring it, proposing amendments, caucusing with its authors, or simply by voting for it. By the end of each conference during this study, 
nearly every committee had passed at least one resolution, and some had passed three or four. Evelyn expressed enormous satisfaction for what she and her peers achieved at the November conference:

We got through four resolutions, which was incredible.... Since these were relevant to Afghanistan [the country we represented], we knew the issues very well. This meant we could convince the delegates to see our viewpoint. Our winning the best delegation award [at the conference] is proof that we were successful.... Our team was one of the reasons we were able to get through four different topics. (interview, December 11, 2009)

When recounting stories about their successes at conferences, participants tended to speak with pride about what they had accomplished, suggesting substantial confidence.

Beyond conferences, EMUN members had repeated opportunities to pursue and achieve collective goals by planning club-focused events, such as fundraisers, recruitment efforts, and delegate training events. These and other club-focused events often yielded tangible results, such as money for conference scholarships. Such experiences appeared to strengthen members' beliefs that they could work with others to achieve collective goals.

Practicing political skills. EMUN members had numerous opportunities to practice various political skills, and such practice appeared to support their development of IPE/skills. Among their most commonly employed political practices was their use of persuasive communication skills, often via public speaking and small-group political dialogue. During club meetings, conference committees, and country delegation meetings, students expressed their perspectives on complex topics, ranging from how to distribute Iraq's oil revenues to whether or not EMUN should become a non-profit organization. In these settings, participants leveraged the 
political knowledge they had developed through their research, considered divergent perspectives on these issues, and often reached collective decisions about social and political complexities. Brad credited these experiences with helping him to adopt a broader understanding of political conflicts (interview, March 8, 2010), and other members indicated that conference debates had required them to explore diverse views on numerous issues, such as the IsraeliPalestinian conflict and rights of free expression in developing countries.

Most interviewees mentioned public speaking as a major area of improvement during their time in the club, and my data suggest that repeated opportunities for practice in this domain facilitated these comfort levels. Julia, for example, noted that her experiences making speeches in committees had enabled her to be more deliberate and extemporaneous. She framed her experiences as "exercising" her public speaking skills:

You know, it's like I didn't pay my 10 bucks to come to [a conference] and, you know, sit here.... You have to be able to think quickly and go up and present your ideas and I'd like to challenge myself. [It's like] I'm exercising, and I'm doing pushups and I'm like, “Okay, well, I'm just going to do ten. Okay, I'll do an extra one.” They go well, and if you are going to do 11, I might as well do 15. I'm doing 15 , [so] I should do $20 \ldots$. The parallel is how much I'm willing to push myself and go up and speak and to think quickly and to share my ideas. (interview, February 8, 2010) Julia's analogy captures the role of repeated practice in many members' experiences. Numerous interviewees said that speaking in front of others became easier and more comfortable with each successive experience. 
EMUN members also had opportunities to practice other persuasive communication skills at conferences by, for example, working in groups to write resolutions or convincing other delegates to vote for those measures. Whereas freshman Erin emphasized that she had learned to get her "voice across more professionally" (interview, March 1, 2010), new junior member Emily said that it was easier to build alliances through "being a relatable person [that other delegates] seem more inclined to vote with" (interview, January 25, 2010). Evelyn agreed that while logical arguments were helpful, a personal touch, even flirting, could help to win votes. Although most interviewees, such as Brad, indicated that conference experiences had helped them at "just really knowing about how to argue my points" (interview, March 8, 2010), many appeared to develop a sense that persuasion was related to both argumentation and personal connection.

In addition to practicing persuasive communication, EMUN members had experiences conducting strategic decision-making - identifying and analyzing potential pathways and obstacles in pursuit of a goal. Designing and passing resolutions at conferences often required building alliances with delegates who shared common interests, but forging these connections involved strategically pursuing partnerships. During the November conference, Evelyn and two other experienced members represented Afghanistan in a simulation of the UN General Assembly, and to get their resolutions passed, they divided responsibilities to recruit votes for upcoming resolutions while speeches on other issues were underway. As she explained:

[Our delegation] ... knows how to pick people who are gonna work with us and help us reach our goal.... We used a strategy where one person would stay at [our country's] table and someone would be caucusing.... By the time the next topic [in 
the debate forum] came around, we were already ready with amendments....We talked to so many countries individually. (interview, December 11, 2009)

Some new members made comments indicating that they had begun to think more strategically about how to get their resolutions passed. At her second conference, Julia indicated the importance of seeking support from delegates likely to give speeches so that they could collectively build support for a resolution.

EMUN members also engaged in strategizing for the development of the club. At semiannual strategic planning meetings ("SPlaM"), students dis-cussed how to strengthen their organization. At Spring SPlaM in March, eight members discussed how to make the following September a strong month for membership recruitment, and the same meeting included a 25minute discussion of how to fairly distribute fundraiser proceeds to reduce students' conference fees. There were similar discussions throughout the study period, often at regular officers' meetings. While Mr. Kendall occasionally contributed by sharing information about how the club had addressed certain challenges in earlier years, he did not lead or dominate the discussion, instead allowing students to reach their own conclusions.

Besides practicing strategic planning and persuasive communication, EMUN members regularly worked on tasks requiring negotiation (e.g., inter-personal cooperation, compromise, and consensus-building). Randall characterized the development of resolutions as an ongoing act of negotiation: "When resolutions are being written, you can, like, see that the way you choose to word things.... I like playing with the language to get it perfectly so everyone, so it's hard to be against it" (interview, October 9, 2009). Even freshman Mark indicated his growing understanding that compromise was often required in politics: 
You're not gonna persuade them from the country's policy ... [but] you might be able to sway them a little bit to agree at a moderate level if you have two extremes. And maybe you can get everyone to agree on one thing. (interview, March 5, 2010)

Like other interviewees, Mark noted that with each conference, his ability to work with people collaboratively had improved (interview, January 16, 2010). To help new members practice such skills, officers used some club meetings to hold mock debates and then debrief, teaching newer members how to find a middle ground between two opposing positions.

Club meetings were also an environment where students practiced negotiation skills. At August SPlaM, 10 students spent a half hour discussing strategies for increasing club members' involvement. Whereas Evelyn said that more out-of-school social events for members would foster bonds and thereby boost meeting attendance, others argued that breaking up cliques during club meetings was crucial and that more mock debates during meetings would generate excitement about conferences. Finally, they came to an agreement that they would try several tactics during the upcoming year but that they would start by having a highly interactive first meeting. In these experiences, students practiced negotiation skills by listening to one another, building on each other's comments, finding common ground, and building consensus. Repeated opportunities for practicing political skills appeared to support students' political efficacy development.

\section{DISCUSSION}

This study indicates that students' political efficacy increased during the process of becoming active, central participants in their Model UN club, which involved repeated opportunities for engaging in political tasks and preparing for those tasks, all within a context of 
supportive, politically engaged peers (see Figure 1). Having numerous chances to participate in politically oriented problem solving and to thoughtfully prepare for these experiences appeared to help participants identify the nuances involved in thriving in such a community and enabled them to actively engage once they felt prepared to do so. Overall, these findings suggest that ongoing opportunities to be involved in a socially supportive group engaged in interactive, politically oriented tasks can support young people's development of political efficacy. These findings strengthen our understanding of successful democratic education and have important implications.

Figure 1. Supportive Relationships with Peers and Advisors

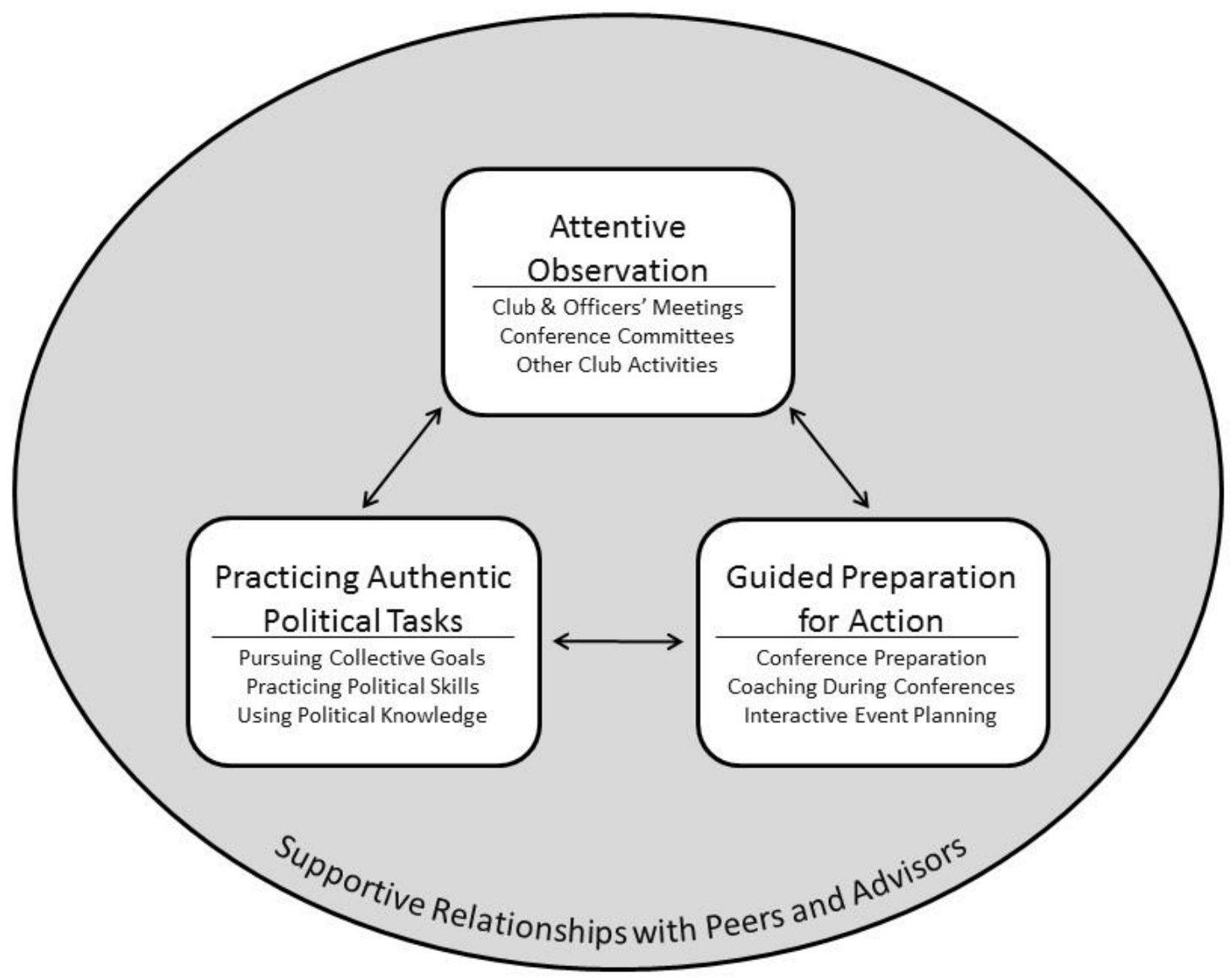




\section{Scholarly Contribution}

This study contributes to a large and growing body of literature examining political efficacy development among youth. Prior research has identified factors and experiences that support political efficacy, such as political discussions (Morrell, 2005) and political simulations (Dressner, 1990), but few studies have longitudinally examined students regularly engaged in these experiences to explore how and why they have this effect. Some political scientists (e.g., Beaumont, 2010) have provided theoretical rationales under-lying these and other possible paths to increased political efficacy, such as social encouragement and skill development, and more empirical exploration of these rationales is needed. The present study builds on this valuable work by examining high school students' experiences over seven months as they negotiated and developed their political efficacy in an interactive social learning environment.

This study provides a vivid and unique illustration of how political efficacy develops among youth in an authentic educational setting and identifies key social factors that support this development. Like the present study, substantial previous research indicates that authentic political participation can support political efficacy (e.g., Ikeda et al., 2008), but few secondary students engage in such activities. The findings above suggest that supportive relationships may be very helpful both for securing young people's initial involvement in such work and for maintaining their continual engagement.

Once youth regularly participate in such experiences, they can become more integrated into a politically oriented community of practice-learning through participation, coparticipation, and legitimate peripheral participation in various activities (Lave \& Wenger, 1991). In the context of a Model UN club or other civic group, this process could involve preparing for participation through observing others and/or seeking guidance. With appropriate 
support and ongoing involvement, participants are more likely to have enactive mastery experiences (Bandura, 1997) that could support their self-efficacy in the political domain. Indeed, the data suggest that greater involvement leads to more gains in IPE/knowledge. Whereas theories of social learning suggest how youth can become integrated into civic and political groups and clubs, this study helps to clarify the potential processes and outcomes involved.

\section{Practical Implications}

This study has several helpful implications for educational practice. Among our sample, students were more likely to become and remain involved in optional after-school Model UN activities if they had positive, supportive relationships with others in the club. EMUN offered numerous ways for members to develop rapport with each other, and friendships among members supported participation in club events and communication about EMUN-related issues beyond scheduled club activities. These findings align with prior research, which suggests that strong, reciprocal relationships can increase the positive impact of programs for youth (e.g., Li \& Julian, 2012) and that dense social networks can support greater political engagement (Leighley $\&$ Vedlitz, 1999). Thus, educators who aim to foster engagement in extracurricular political clubs should consider ways to foster friendships among the group's members, especially new members who may feel marginalized from the group's shared culture and history.

Ultimately, such positive relationships can foster students' regular attendance and participation in a community of practice. In EMUN, regular participants had repeated opportunities to observe skilled peers, engage in guided preparation for action, and practice authentic political tasks, which appeared vital for supporting their political efficacy. As Bandura's (1997) social cognitive theory argues, individuals base their self-efficacy for specific 
tasks on their prior performance on similar tasks, and students in this study often practiced a skill several times before expressing more confidence in it, with multiple opportunities to plan, revise, and reflect on their own actions and strategies, which led them to reassess their judgments about their own abilities.

In many schools, educators do indeed enact lessons that give students the chance to observe and practice political knowledge and skills (e.g., mock trials, debates), but often these experiences are brief or infrequent. If classroom teachers and school leaders are interested in fostering students' political efficacy, they should consider ways to provide students multiple opportunities to engage in such activities, perhaps through innovative course designs that regularly integrate political role plays, discussions, and simulations (e.g., Lo, 2017; Lo \& Parker, 2016; Parker et al., 2013).

\section{Research Implications}

This study raises several questions for future researchers to investigate. Whereas the present study examined the development of political efficacy, an attitude closely associated with political participation, it is also important that researchers examine the development of other political attitudes, such as tolerance and open-mindedness. As Parker (2003) has noted, a sustainable, diverse democracy requires that citizens be not only actively engaged but also considerate and understanding of those who are different from themselves. This stance is especially important during the current era of increasing political polarization (Pew Research Center, 2014). Furthermore, political skills, including many that EMUN members practiced, are vital to successful political action. Whereas this study explored students' development of selfefficacy for such skills, future research should examine the development of students' actual political skills, such as negotiation and communication. 
Given the positive civic learning outcomes for students in EMUN and other civically oriented social learning programs (e.g., Bixby, 2008), it is important to explore how more students could have such experiences and the outcomes for different types of students. Kahne and Middaugh (2008) have found that students from minority backgrounds and those who attend schools that draw from low socioeconomic populations are less likely to experience engaging civic learning opportunities in school, and Levinson (2012) has contended that this opportunity gap creates a "civic empowerment gap" between those with substantial economic resources and those with few. To address this problem, Levinson (2013) has argued that more active learning programs, rather than information-driven civics courses, can help generate more political efficacy and participation. The present study, though set in a middle-class area, supports her contention, providing evidence that active civic learning can support political efficacy. Given the persistence of the civic opportunity gap, future studies should examine how such experiences can support youth civic development in high-poverty areas, as well as what the challenges are in various contexts. In such studies, it would be useful to explore how students who differ by race, sex, class, or other characteristics learn through these experiences (Hahn \& Quaynor, 2012; Pinkney, 2016).

Finally, it is important to assess the duration and arc of changes in attitudes, skills, or knowledge that young people experience through civic learning programs. The present study lasted seven months and found positive changes in students' political efficacy, but due to limited time and resources, I was unable to measure the extent to which these changes endured, increased, or disappeared beyond those seven months. This study and prior research indicate that having multiple opportunities to practice new skills over time, especially with expert feedback, can yield substantial growth (e.g., Porte, Zeroulis, Reznick, \& Dubrowski, 2007), but the long- 
term effects of such experiences on political attitudes and engagement have not been examined.

In future studies examining civic and political learning, researchers should attempt to study students over longer periods of time in order to explore not only their development during the experience, but also any effects that such experiences may have long afterwards.

\section{LIMITATIONS AND CONCLUSION}

This study documented useful findings about the development of political efficacy through social learning experiences, but it is important to acknowledge its limitations. First, this study included a small participant sample of White, middle-class students in one Midwestern high school during the early years of the Obama administration, and different students within a different context may not experience the same political efficacy changes that these students did, even given similar opportunities. In addition, the two groups in this study had different levels of IPE/knowledge at Time 1, and this difference may have accounted for some of the differences at Time 2. Finally, EMUN had a long history and highly committed advisors. Although some Model UN and other groups fit this model, there is tremendous diversity in the operations, structure, and composition of such groups.

Despite these limitations, this study illustrates how an extracurricular politically oriented education program can support the development of adolescents' political efficacy, a reliable predictor of various forms of political participation, by providing opportunities for increasing involvement in social learning experiences. Although participation was optional, the support of peers and advisors encouraged club members to engage in the club's activities, which then enabled them to regularly observe skilled peers, receive useful guidance, and practice authentic political tasks. Researchers can build on these findings by examining how different programs and experiences might support adolescents' civic and political learning in diverse contexts over time. 
Continuing to explore and enact methods of preparing young people for political participation is vital to strengthening our democracy.

\section{FUNDING}

Funding for this research was provided by the Rackham Graduate School at the University of Michigan, and I greatly appreciate their support.

\section{NOTES}

${ }^{1}$ There was a significant increase in EMUN students' IPE/skills from Time 1 to Time 2. There was a significant decline in NHS students' EPE from Time 1 to Time 2. Table 2 indicates differences only between groups at each time point.

${ }^{2}$ In the regression models examining EPE and both IPE dimensions, the demographic variables had no statistically significant effect at Time 2 . This was the also the case for race and GPA, which I excluded from the final calculations to create parsimonious models with more degrees of freedom. In my examination of multi-collinearity, variance inflation factors for all three models were within acceptable ranges (below 2.5).

${ }^{3}$ Variance inflation factors for these regression analyses were all within acceptable limits (below 2.5). 


\section{REFERENCES}

Abrams, D., \& De Moura, G. R. (2002). The psychology of collective political protest. In V. C. Ottati, R. F. Tindale, J. Edwards, F. B. Bryant, L. Heath, D. C. O’Connell, ... E. J. Posavac (Eds.), The social psychology of politics (pp. 193-214). New York, NY: Springer.

Balch, G. (1974). Multiple indicators in survey research: The concept 'sense of efficacy'. Political Methodology, 1, 1-49.

Bandura, A. (1997). Self-efficacy: The exercise of control. New York, NY: Freeman.

Bandura, A. (2005). Adolescent development from an agentic perspective. In T. Urdan \& F. Pajares (Eds.), Self-efficacy beliefs of adolescents (pp. 1-43). Charlotte, NC: Information Age.

Beaumont, E. (2010). Political agency and empowerment: Pathways for developing a sense of political efficacy in young adults. In L. R. Sherrod, J. Torney-Purta, \& C. A. Flanagan (Eds.), Handbook of research on civic engagement in youth (pp. 525-558). Hoboken, NJ: Wiley.

Beaumont, E. (2011). Promoting political agency, addressing political inequality: A multilevel model of internal political efficacy. Journal of Politics, 73(1), 216-231. doi:10.1017/S0022381610000976

Becker, R. (2005). Political efficacy and voter turnout in East and West Germany. Swiss Political Science Review, 11(1), 57-86. doi:10.1002/ j.1662-6370.2005.tb00048.x

Bernstein, J. L. (2008). Cultivating civic competence: Simulations and skill-building in an introductory government class. Journal of Political Science Education, 4(1), 1-20. doi:10.1080/15512160701815996 
Bixby, J. S. (2008). To think, live, and breathe politics: Experiencing democratic citizenship in Chicago. In J. S. Bixby \& J. L. Pace (Eds.), Educating citizens in troubled times: Qualitative studies of current efforts. Albany, NY: SUNY Press.

Blankenship, G. (1990). Classroom climate, global knowledge, global attitudes, political attitudes. Theory \& Research in Social Education, 18, 363-386.

doi:10.1080/00933104.1990.10505622

Bowler, S., \& Donovan, T. (2002). Democracy, institutions, and attitudes about citizen influence on government. British Journal of Political Science, 32(2), 371-390. doi:10.1017/S0007123402000157

Button, C. B. (1972). The development of experimental curriculum to effect the political socialization of Anglo, Black and Mexican-American adolescents (Unpublished doctoral dissertation). The University of Texas at Austin.

Calabrese Barton, A., \& Tan, E. (2010). We be burnin'!: Agency, identity, and science learning. Journal of the Learning Sciences, 19(2), 187-229. doi:10.1080/10508400903530044

Campbell, A., Gurin, G., \& Miller, W. (1954). The voter decides. Evanston, IL: Row, Peterson.

Christens, B. D., Peterson, N. A., \& Speer, P. W. (2011). Community participation and psychological empowerment: Testing reciprocal causality using a cross-lagged panel design and latent constructs. Health Education \& Behavior, 38(4), 339-347. doi: $10.1177 / 1090198110372880$

Clarke, H. D., \& Acock, A. C. (1989). National elections and political attitudes: The case of political efficacy. British Journal of Political Science, 19(4), 551-562. doi:10.1017/S0007123400005639 
Cohen, A., Vigoda, E., \& Samorly, A. (2001). Analysis of the mediating effect of personalpsychological variables on the relationship between socio-economic status and political participation: A structural equations frame-work. Political Psychology, 22(4), 727-757. doi:10.1111/pops.2001.22. issue-4

Craig, S. C. (1979). Efficacy, trust and political behavior: An attempt to resolve a lingering conceptual dilemma. American Politics Quarterly, 7(2), 225-239. doi:10.1177/1532673X7900700207

Craig, S. C., Niemi, R. G., \& Silver, G. E. (1990). Political efficacy and trust: A report on the NES pilot study items. Political Behavior, 12(3), 289-314. doi:10.1007/BF00992337

Dressner, M. M. (1990). Changing energy end-use patterns as a means of reducing globalwarming trends. The Journal of Environmental Education, 21(2), 41-46.

Eccles, J. S. (2005). Subjective task value and the Eccles et al. model of achievement-related choices. In A. J. Elliot \& C. S. Dweck (Eds.), Handbook of competence and motivation (pp. 105-121). New York, NY: Guilford Press.

Ehman, L. H. (1969). An analysis of the relationships of selected educational variables with the political socialization of high school students. American Educational Research Journal, 6, 559-580. doi:10.3102/00028312006004559

Ehman, L. H. (1980). The American school in the political socialization process. Review of Educational Research, 50, 99-119. doi:10.3102/ 00346543050001099

Finkel, S. E. (1987). The effects of participation on political efficacy and political support: Evidence from a West German panel. The Journal of Politics, 49(2), 441-464. doi: $10.2307 / 2131308$ 
Fredrickson, B. L. (1998). What good are positive emotions? Review of General Psychology, 2(3), 300-319. doi:10.1037/1089-2680.2.3.300

Freie, J. F. (1997). The effects of campaign participation on political attitudes. Political Behavior, 19(2), 133-156. doi:10.1023/A:1024858108803

Glaser, B., \& Strauss, A. (1967). Discovery of grounded theory. Chicago, IL: Aldine.

Hahn, C. L. (1998). Becoming political: Comparative perspectives on citizenship education. Albany: State University of New York Press.

Hahn, C. L. (1999). Citizenship education: An empirical study of policy, practices, and outcomes. Oxford Review of Education, 25(1-2), 231-250. doi:10.1080/030549899104233

Hahn, C. L., \& Quaynor, L. (2012). Gender and civic education. In J. A. Banks (Ed.), Encyclopedia of diversity in education (pp. 942-950). New York, NY: Sage.

Hirlinger, M. W. (1992). Citizen-initiated contacting of local government officials: A multivariate explanation. The Journal of Politics, 54(2), 553-564. doi:10.2307/2132039

Hollandsworth, J. G., Glazeski, R. C., Kirkland, K., Jones, J. E., \& Van Norman, L. R. (1979). An analysis of the nature and effects of test anxiety: Cognitive, behavioral, and physiological components. Cognitive Therapy and Research, 3, 165-180. doi:10.1007/BF01172603

Ikeda, K., Kobayashi, T., \& Hoshimoto, M. (2008). Does political participation make a difference? The relationship between political choice, civic engagement and political efficacy. Electoral Studies, 27(1), 77-88. doi:10.1016/j.electstud.2007.11.004

Kahne, J., \& Middaugh, E. (2008). Democracy for some: The civic opportunity gap in high school (CIRCLE Working Paper 59). Center for Information and Research on Civic 
Learning and Engagement, Retrieved from http://

www.civicyouth.org/PopUps/WorkingPapers/WP59Kahne.pdf

Kirshner, B. (2008). Guided participation in three youth activism organizations: Facilitation, apprenticeship, and joint work. Journal of the Learning Sciences, 17(1), 60-101. doi:10.1080/10508400701793190

Koch, J. W. (1993). Assessments of group influence, subjective political competence, and interest group membership. Political Behavior, 15(4), 309-325.

doi:10.1007/BF00992100

Lambert, R. D., Curtis, J. E., Brown, S. D., \& Kay, B. J. (1986). Effects of identification with governing parties on feelings of political efficacy and trust. Canadian Journal of Political Science, 19(4), 705-728. doi:10.1017/ S0008423900055116

Lave, J., \& Wenger, E. (1991). Situated learning: Legitimate peripheral participation. Cambridge: Cambridge University Press.

Lee, K. (2006). Effects of Internet use on college students' political efficacy. CyberPsychology \& Behavior, 9(4), 415-422. doi:10.1089/cpb.2006.9.415

Leighley, J. E., \& Vedlitz, A. (1999). Race, ethnicity, and political participation: Competing models and contrasting explanations. Journal of Politics, 61(4), 1092-1114. doi: $10.2307 / 2647555$

Levinson, M. (2012). No citizen left behind. Cambridge, MA: Harvard University Press.

Levinson, M. (2013). Education as a civic right: Using schools to challenge the civic empowerment gap. Poverty and Race, 22(3), 1-2, 10-13. 
Levy, B. L. M. (2011). "I could make a difference": Research and theory on educating adolescents for political engagement (Unpublished doctoral dissertation). Ann Arbor: University of Michigan.

Levy, B. L. M. (2013). An empirical exploration of factors related to adolescents' political efficacy. Educational Psychology, 33(3), 357-390. doi:10.1080/01443410.2013.772774

Levy, B. L. M. (2016). Advising a Model United Nations club: A scaffolded youth-adult partnership to foster active participation and political engagement. Teaching and Teacher Education, 59(1), 13-27. doi:10.1016/j. tate.2016.04.001

Li, J., \& Julian, M. M. (2012). Developmental relationships as the active ingredient: A unifying working hypothesis of "what works" across intervention settings. American Journal of Orthopsychiatry, 82(2), 157-166. doi:10.1111/j.1939-0025.2012.01151.x

Livingston, S. A., \& Kidder, J. J. (1972). Effects of a legislative simulation game on the political attitudes of junior high school students. Simulation and Games, 3, 41-51. doi:10.1177/104687817200300104

Lo, J. C. (2017). Adolescents developing civic identities: Sociocultural perspectives on simulations and role-play in a civic classroom. Theory \& Research in Social Education, 45(2), 189-217. doi:10.1080/ 00933104.2016.1220877

Lo, J. C., \& Parker, W. C. (2016). Role-playing and role-dropping: Political simulations as portals to pluralism in a contentious era. In W. Journell (Ed.), Reassessing the social studies curriculum: Promoting critical civic engagement in a politically polarized, post 9-11 world (pp. 95-108). Lanham, MD: Rowman \& Littlefield. 
Louis, W. R., Taylor, D. M., \& Neil, T. (2004). Cost-benefit analyses for your group and yourself: The rationality of decision-making in conflict. International Journal of Conflict Management, 15(2), 110-143. doi:10.1108/eb022909

McAdam, D. (1988). Freedom summer. New York, NY: Oxford University Press.

Merton, R. K., Fiske, M., \& Kendall, P. L. (1990). The focused interview. New York, NY: Free Press.

Miller, A. H., Goldenberg, E. N., \& Erbring, L. (1979). Type-set politics: Impact of newspapers on public confidence. The American Political Science Review, 73(1), 67-84. doi:10.2307/1954731

Morrell, M. E. (2005). Deliberation, democratic decision-making and internal political efficacy. Political Behavior, 27(1), 49-69. doi:10.1007/s11109- 005-3076-7

Myers, J. P., McBride, C. E., \& Anderson, M. (2015). Beyond knowledge and skills: Discursive construction of civic identity in the world history classroom. Curriculum Inquiry, 25(2), 198-218. doi:10.1080/ 03626784.2015.1011045

Newhagen, J. E. (1994). Media use and political efficacy: The suburbanization of race and class. Journal of the American Society for Information Science, 45(6), 386-394. doi:10.1002/(ISSN)1097-4571

Paglis, L. L., \& Green, S. G. (2002). Leadership self-efficacy and managers' motivation for leading change. Journal of Organizational Behavior, 23(2), 215-235.

Parker, W. (2003). Teaching democracy: Unity and diversity in public life. New York, NY: Teachers College Press.

Parker, W. C., Lo, J., Yeo, A. J., Valencia, S. W., Nguyen, D., Abbott, R. D., \& Vye, N. J. (2013). Beyond breadth-speed-test: Toward deeper knowing and engagement in an 
Advanced Placement course. American Educational Research Journal, 50, 1424-1459. doi:10.3102/ 0002831213504237

Pew Research Center. (2014). Political polarization in the American public: How increasing ideological uniformity and partisan antipathy affect politics, compromise, and everyday life. Washington, DC: Pew Research Center.

Pinkney, A. R. (2016). The role of schools in educating Black citizens: From the 1800s to the present. Theory \& Research in Social Education, 44(1), 72-103. doi:10.1080/00933104.2015.1099486

Porte, M. C., Xeroulis, G., Reznich, R. K., \& Dubrowski, A. (2007). Verbal feedback from an expert is more effective than self-accessed feedback about motion efficiency in learning new surgical skills. The American Journal of Surgery, 193(1), 105-110.

Schunk, D. (1987). Peer models and children's behavioral change. Review of Educational Research, 57(2), 149-174. doi:10.3102/00346543057002149

Schunk, D., \& Cox, P. D. (1986). Strategy training and attributional feedback with learning disabled students. Journal of Educational Psychology, 78(3), 201-209. doi:10.1037/0022-0663.78.3.201

Siegel, M. E. (1977). Citizenship education in five Massachusetts high schools. Theory \& Research in Social Education, 5(2), 31-55. doi:10.1080/00933104.1977.10506005

Smith, R. E. (1989). Effects of coping skills training on generalized self-efficacy and locus of control. Journal of Personality and Social Psychology, 56(2), 228-233. doi:10.1037/0022-3514.56.2.228

Steinberger, P. J. (1981). Social context and political efficacy. Sociology and Social Research, 65(2), 129-141. 
Stenner-Day, K., \& Fischle, M. (1992). The effects of political participation on political efficacy: A simultaneous equations model. Australian Journal of Political Science, 27(2), 282305. doi:10.1080/00323269208402195

Strauss, A., \& Corbin, J. (1999). Basics of qualitative research: Techniques and procedures for developing grounded theory. London, UK: Sage.

Stroupe, K. S., \& Sabato, L. J. (2004). Politics: The missing link of responsible civic education (CIRCLE Working Paper 18). Center for Information and Research on Civic Learning and Engagement. Retrieved from http://civicyouth.org/PopUps/WorkingPapers/ WP18Stroupe.pdf

Torney-Purta, J. (1989). Political cognition and its restructuring in young people. Human Development, 32(1), 14-23. doi:10.1159/000276358

Torney-Purta, J. (1996). Conceptual changes among adolescents using computer networks in group-mediated international role playing. In S. Vosniadou, E. DeCorte, R. Glaser, \& H. Mandl (Eds.), International perspectives on the design of technology supported learning environments (pp. 203-219). Hillsdale, NJ: Erlbaum.

Torney-Purta, J., Amadeo, J., \& Andolina., M. W. (2010). A conceptual framework and a multimethod approach for research in civic engagement and political socialization. In L. Sherrod, J. Torney-Purta, \& C. Flanagan (Eds.), Handbook of research on civic engagement in youth (pp. 497-534). Hoboken, NJ: John Wiley.

Turner, C. (1997). Model United Nations simulations as secondary learning and teaching strategies (Unpublished doctoral dissertation). Auburn University, Auburn, AL.

United Nations Association of the USA. (2015). About Global Classrooms Model UN. Retrieved from http://unausa.org/global-classrooms-model-un/ about-global-classrooms-model-un 
Wells, S. D., \& Dudash, E. A. (2007). Wha'd'ya know? Examining young voters' political information and efficacy in the 2004 election. American Behavioral Scientist, 50(9), 1280-1289. doi:10.1177/0002764207300053

Wenger, E. (1998). Communities of practice: Learning, meaning, and identity. Cambridge: Cambridge University Press.

Wigfield, A., \& Eccles, J. S. (2000). Expectancy-value theory of achievement motivation. Contemporary Educational Psychology, 25, 68-81. doi:10.1006/ceps.1999.1015

Williams, J. (2009). Global Classrooms Marks a Decade of Model UN. UNA-USA World Bulletin. Retrieved October 10, 2009, from http://www. unausa.org/Page.aspx?pid1/41284

Wright-Maley, C. (2015a). Beyond the "Babel problem": Defining simulations for the social studies. Journal of Social Studies Research, 39(2), 63-77. doi:10.1016/j.jssr.2014.10.001

Wright-Maley, C. (2015b). On "stepping back and letting go": The role of control in the success or failure of social studies simulations. Theory \& Research in Social Education, 43(2), 206-243. doi:10.1080/ 00933104.2015.1034394

Zeldin, S., Christens, B. D., \& Powers, J. L. (2013). The psychology and practice of youth-adult partnership: Bridging generations for youth development and community change. American Journal of Community Psychology, 51(3-4), 385-397. doi:10.1007/s10464012-9558-y

Zimmerman, B. J., Bandura, A., \& Martinez-Pons, M. (1992). Self-motivation for academic attainment: The role of self-efficacy beliefs and personal goal-setting. American Educational Research Journal, 29(3), 663-676. doi:10.3102/00028312029003663 


\section{APPENDIX A}

Supplemental Statical Findings

Table A1. Characteristics of Model UN and NHS Students ( $N=63 ; M U N N=36, N H S N=27)$

\begin{tabular}{lcc}
\hline Variable & Model UN Students & NHS Students \\
\hline Mean GPA & 3.8 & 3.7 \\
Mean Age & $15.8^{*}$ & 16.4 \\
\% Ethnic Minority & 3.2 & 7.7 \\
\% Mothers with college degrees or more & 60.6 & 65.4 \\
$\%$ Fathers with college degrees & 63.6 & 53.8 \\
\hline
\end{tabular}

$* * * \mathrm{p}<.001, * * \mathrm{p}<.01, * \mathrm{p}<.05, \sim \mathrm{p}<.1$

Table A2. Results of Principal Component Analyses

\begin{tabular}{lcc}
\hline Scale & \# Items & Cronbach's Alpha \\
\hline IPE/Skills, Time 1 & 4 & .56 \\
IPE/Skills, Time 2 & 4 & .76 \\
IPE/Knowledge, Time 1 & 4 & .70 \\
IPE/Knowledge, Time 2 & 4 & .75 \\
External Political Efficacy, Time 1 & 3 & .86 \\
External Political Efficacy, Time 2 & 3 & .84 \\
Parental Education* & 2 & .73 \\
\hline
\end{tabular}

*Parental education is the only demographic characteristic measured by more than one variable. 


\section{APPENDIX B}

Table B1. Scale Items and Key Variables

\begin{tabular}{|c|c|c|}
\hline $\begin{array}{l}\text { Scale/ } \\
\text { Variable }\end{array}$ & Item Question(s)/Statement(s) & $\begin{array}{l}\text { Response Choices } \\
\text { (seven levels unless otherwise noted) }\end{array}$ \\
\hline \multirow{3}{*}{$\begin{array}{l}\text { External } \\
\text { Political } \\
\text { Efficacy }\end{array}$} & $\begin{array}{l}\text { Do you think that your words and/or actions could persuade } \\
\text { a state elected official to consider your policy views? }\end{array}$ & Definitely Could Not Persuade - \\
\hline & $\begin{array}{l}\text { Do you think that your words and/or actions could actually } \\
\text { affect the outcome of local policy? }\end{array}$ & Definitely Could Persuade \\
\hline & $\begin{array}{l}\text { Do you think that your words and/or actions could actually } \\
\text { affect the outcome of state policy? }\end{array}$ & $\begin{array}{l}\text { Definitely could not affect the outcome } \\
\text { - Definitely could affect the outcome }\end{array}$ \\
\hline \multirow{4}{*}{$\begin{array}{l}\text { Internal } \\
\text { Political } \\
\text { Efficacy/ } \\
\text { Knowledge }\end{array}$} & $\begin{array}{l}\text { I feel that I have a pretty good understanding of the } \\
\text { important political issues facing our country. }\end{array}$ & $\begin{array}{l}\text { No Understanding - } \\
\text { Excellent Understanding }\end{array}$ \\
\hline & $\begin{array}{l}\text { Ifeel that I have a pretty good understanding of the } \\
\text { important political issues facing our world. }\end{array}$ & $\begin{array}{l}\text { No Understanding - } \\
\text { Excellent Understanding }\end{array}$ \\
\hline & $\begin{array}{l}\text { I often don't feel sure of myself when talking with other } \\
\text { people about politics and government. [reverse coded] }\end{array}$ & $\begin{array}{l}\text { Very Strongly Disagree - } \\
\text { Very Strongly Agree }\end{array}$ \\
\hline & $\begin{array}{l}\text { Sometimes politics and government seem so complicated } \\
\text { that a person like me can't really understand. }\end{array}$ & $\begin{array}{l}\text { Very Strongly Disagree - } \\
\text { Very Strongly Agree }\end{array}$ \\
\hline \multirow{4}{*}{$\begin{array}{l}\text { Internal } \\
\text { Political } \\
\text { Efficacy/ } \\
\text { Skills }\end{array}$} & $\begin{array}{l}\text { When I have to work with other people to achieve a goal, I } \\
\text { can motivate others to complete the tasks involved. }\end{array}$ & Never - Always \\
\hline & $\begin{array}{l}\text { I am confident that I can construct arguments about } \\
\text { political issues (in writing or speech) that are logical and } \\
\text { well-reasoned. }\end{array}$ & $\begin{array}{l}\text { Not at all Confident - } \\
\text { Extremely Confident }\end{array}$ \\
\hline & $\begin{array}{l}\text { I can persuade my peers of my point of view on political } \\
\text { issues. }\end{array}$ & Never - Always \\
\hline & $\begin{array}{l}\text { When I disagree with a peer, I am comfortable expressing } \\
\text { my point of view to him or her. }\end{array}$ & Never - Always \\
\hline \multirow{4}{*}{$\begin{array}{l}\text { Political } \\
\text { Interest } \\
\text { EMUN } \\
\text { Participation }\end{array}$} & How much do you like learning about political issues? & Not at all - Tremendously \\
\hline & How often do you attend meetings for Model UN? & $\begin{array}{l}\text { Less than once per month - } \\
\text { More than once per week (five levels) }\end{array}$ \\
\hline & $\begin{array}{l}\text { In how many Model UN fundraisers have you participated } \\
\text { this year? }\end{array}$ & $0-3$ or more (four levels) \\
\hline & $\begin{array}{l}\text { What is the total number of high school Model UN } \\
\text { conferences that you have attended? }\end{array}$ & $0-8$ or more (nine levels) \\
\hline $\begin{array}{l}\text { EMUN } \\
\text { Friends }\end{array}$ & $\begin{array}{l}\text { How many friends would you say that you have in your } \\
\text { school's Model UN club? }\end{array}$ & $0-8$ or more (nine levels) \\
\hline
\end{tabular}




\section{APPENDIX C}

Features of EMUN Club Experiences

Table C1. Elmwood High School Model UN Club's Activities

\begin{tabular}{lll}
\hline Activity & Duration & Frequency \\
\hline Interscholastic Conferences & $1-4$ days & 4 per year (3 during study period) \\
Conference Preparation Meetings (small groups) & $1-2$ hours & Usually 2-4 times per conference \\
Full Club Meetings & 1 hour & Weekly \\
Officers' Meetings & 1 hour & Weekly \\
Fundraisers & $1-5$ days & 5 per year \\
Strategic Planning Meetings & $4-6$ hours & 2 per year \\
Educational Events (for non-members) & $1-6$ hours & $2-4$ per year \\
\hline
\end{tabular}

Table C2. Opportunities for EMUN Students to Develop Relationships

\begin{tabular}{lll}
\hline Structured Club Experiences & Informal Club Experiences & Beyond the Club \\
\hline Conference Preparation & Humor at Meetings & Lunchtime \\
Conference Trips & Time for Informal Talk & Classes \\
Structured Rapport-Building & & Outside of School \\
Frequent Contact & & \\
\hline
\end{tabular}

Table C3. Committees and Debate Topics at a Model UN Conference attended by Elmwood Students

\begin{tabular}{ll}
\hline Committee & Debate Topics \\
\hline Human Rights Council & $\begin{array}{l}\text { Freedom of the Press } \\
\text { Rights of Lesbian and Gay Individual }\end{array}$ \\
\cline { 2 - 2 } Social and Economic Committee & $\begin{array}{l}\text { International Labor Standards } \\
\text { Indigenous Land Rights }\end{array}$ \\
\cline { 2 - 2 } World Health Organization & Pandemic Flu \\
Security Council & Access to Safe Drinking Water \\
\cline { 2 - 2 } Political Committee & $\begin{array}{l}\text { Afghanistan's Instability } \\
\text { Iran's Nuclear Program }\end{array}$ \\
\cline { 2 - 2 } Special Political Committee & $\begin{array}{l}\text { Illicit Trade in Small Arms } \\
\text { Electoral Violence and Intimidation }\end{array}$ \\
\cline { 2 - 2 } Social, Cultural, and Humanitarian Committee & Situation in Korean Peninsula \\
& Israeli-Palestinian Conflict \\
\hline & Children in Armed Conflict \\
\hline
\end{tabular}

Note. Table originally published in Levy, 2016. (C) Elsevier. Reproduced by permis- sion of Elsevier. Permission to reuse must be obtained from the rightsholder. 